\title{
Artificial scents have no place in our hospitals
}

\author{
Ken Flegel MD, James G. Martin MD
}

$\mathrm{T}$ here are many practices that are acceptable outside hospitals - but not inside. One of these is the application of artificial scents to our bodies. While artificial scents are designed to make us more attractive, they may result in unintended harm to those who are vulnerable.

According to large surveys of the general public, about $30 \%$ of people report having some sensitivity to scents worn by others. ${ }^{1}$ Twenty-seven percent of people with asthma say their disease is made worse by such exposures. ${ }^{2}$ There is emerging evidence that asthma in some cases is primarily aggravated by artificial scents. This is particularly concerning in hospitals, where vulnerable patients with asthma or other upper airway or skin sensitivities are concentrated. These patients may be involuntarily exposed to artificial scents from staff, other patients and visitors, resulting in worsening of their clinical condition. As patients, family members and emergency physicians will attest, the attacks can be quite sudden and serious. There is little justification for continuing to tolerate artificial scents in our hospitals.

Federal and provincial human rights acts require accommodation for employees who are sensitive to scents in the workplace, but not for patients in hospitals or clinics. ${ }^{3}$ Some workers have successfully sued companies to have workplace policies changed regarding scents. In a work setting, a susceptible individual can speak directly to a colleague or manager, or arrange for a scent-free work environment and this is supported by law. For patients, however, these opportunities do not exist.

Many readers may be skeptical that sensitivity to artificial scents exists, but we now have a better understanding of the basis of reactions to these products. Less than half (47\%) of the burden of asthma is attributable to allergic, eosinophilic mechanisms, with much of the remainder considered to be caused by irritant-triggered neutrophilic inflammation in the airways. ${ }^{4}$ People with asthma report symptoms triggered by a range of stimuli that do not fall into the category of allergens. These substances include second-hand cigarette smoke, cleaning fluids such as bleach, perfume and other strong odours. Such irritants have been neglected for some time as important triggers in asthma because it was thought that they were not disease-causing, but rather disease-exacerbating.

A family of receptors has been identified on sensory nerves within the airways that react to noxious stimuli, causing cough and bronchospasm. ${ }^{5,6}$ These receptors - transient receptor potential channels - may recognize and be activated by heat, cold and osmolar gradients, as well as oxidants, capsaicin and other substances. The resultant release of neuropeptides may cause immediate effects, such as bronchoconstriction and mucus secretion; secondary neurogenic inflammation may prolong the consequences of exposure. The risk of experiencing symptoms from exposure to scents has been reportedly related to the presence of airway hyperresponsiveness, a defining characteristic of asthma, and to the severity of asthma itself. ${ }^{7}$ Some, but not all, studies have also reported an association with atopy. ${ }^{7}$ Nevertheless, some people with asthma may experience serious symptoms in the absence of objective airway narrowing, ${ }^{8}$ which presumably reflects sensations deriving from afferent neural activity in the airways.

We have much to learn about the mechanisms underlying scent sensitivity, but we know enough now to take precautionary measures in our hospitals. Many public places promote a scent-free environment. Some hospitals also do so. But it is not policy in all Canadian hospitals, and it is not required in hospital accreditation standards. The high prevalence of asthma and its adverse effects on health and productivity argue strongly for greater consideration of the air we breathe in our health care centres. Hospital environments free from artificial scents should become a uniform policy, promoting the safety of patients, staff and visitors alike. As education and promotion programs have some effect on this practice, these programs too ought to be part of our accreditation standards. ${ }^{9}$ Until this happens, individual hospitals must take the lead, particularly in spaces where susceptible patients wait.

\section{References}

1. Caress SM, Steinemann AC. Prevalence of fragrance sensitivity in the American popualtion. J Environ Health 2009;71:46-50.

2. Caress SM, Steinemann AC. National prevalence of asthma and chemical hypersensitivity: an examination of potential overlap. J Occup Environ Med 2005;47:518-22.

3. Scent-free policy for the workplace [fact sheet]. Hamilton (ON): Canadian Centre for Occupational Health and Safety; 2015 [updated]. Available: www.ccohs.ca/ oshanswers/hsprograms/scent_free.html (accessed 2015 Sept. 15).

4. Douwes J, Pearce N. Asthma and the westernization "package." Int J Epidemiol 2002;31:1098-102

5. Bautista DM, Jordt SE, Nikai T, et al. TRPA1 mediates the inflammatory actions of environmental irritants and proalgesic agents. Cell 2006;124:1269-82.

6. Song MY, Yuan JX. Introduction to TRP channels: structure, function, and regulation Adv Exp Med Biol 2010;661:99-108.

7. Elberling J, Linneberg A, Dirksen A, et al. Mucosal symptoms elicited by fragrance products in a population-based sample in relation to atopy and bronchial hyperreactivity. Clin Exp Allergy 2005;35:75-81.

8. Millqvist E, Lowhagen O. Placebo-controlled challenges with perfume in patients with asthma-like symptoms. Allergy 1996;51:434-9.

9. Policy for developing a scent-free workplace. Ottawa: The Lung Association; 2003 Available: https://nb.lung.ca/pdf/DevelopingaScentfreePolicyforaWorkplace.pdf (accessed 2015 Sept. 17).

Competing interests: For Ken Flegel's competing interests, see www.cmaj.ca /site/misc/cmaj_staff.xhtml. None declared by James Martin.

Affiliations: Associate Editor (Flegel), CMAJ; Meakins-Christie Laboratories (Martin), Department of Medicine, McGill University, Montréal, Que.

Correspondence to: $C M A J$ editor,pubs@cmaj.ca

CMAJ 2015. DOI:10.1503/cmaj.151097 